\title{
PENDEKATAN BRAINSTORMINGROUND-ROBIN UNTUK MENINGKATKAN KEMAMPUAN KOMUNIKASIMATEMATIS SISWA SMP
}

\author{
Oleh: \\ Maya Siti Rohmah \\ Pendidikan Matematika STKIP Siliwangi Bandung \\ maya_sitirohmah@yahoo.com
}

\begin{abstract}
ABSTRAK
Penelitian ini bertujuan untuk mengetahui peningkatan kemampuan komunikasi matematis siswa yang pembelajarannya menggunakan Brainstorming Round-Robin dibandingkan dengan siswa yang pembelajarannya konvensional. Penelitian kuasi eksperimen ini mengambil populasi siswa kelas VII pada salah satu SMP di kabupaten Bandung Barat dengan sampel 2 kelas. Dari dua kelas yang dipilih dalam penelitian ini, salah satunya digunakan sebagai kelas eksperimen yang memperoleh pembelajaran dengan pendekatan Brainstorming Round-Robin, sedangkan kelas lainnnya sebagai kelas kontrol yang pembelajarannya konvensional. Kedua kelompok diberikan pretes dan postes kemampuan komunikasi matematis. Data N-gain yang diperoleh diuji secara kuantitatif dengan uji perbedaan rerata nonparametrik Mann-Whitney. Hasil penelitian menunjukkan bahwa peningkatan kemampuan komunikasi matematis siswa yang mendapat pembelajaran dengan menggunakan pendekatan Brainstorming Round-Robin lebih baik daripada siswa yang pembelajarannya konvensional.
\end{abstract}

Kata Kunci : Brainstorming Round-Robin, KomunikasiMatematis

\begin{abstract}
The aims of these research are to determine anincrease in mathematics communication of students who obtain learning using Round-Robin Brainstormingbetter thanstudents who receivedconventional learning. This quasi experimental take population all students at class VII in one of public secondary school in West Bandung district with 2 classes as sample. From this 2 classes choosen in this research, one of them as an experimental classthatacquirelearningwithRound-Robin Brainstormingapproach, and the other one as acontrol class that receive conventional learning. Both groups weregiven thepretest and posttest of mathematics communication. N-gain data obtainedquantitatively,testedwitha meandifference testnonparametricMann-Whitney. The results showedthat an achievement and increase inmathematics communication of students thatgetslearning usingRound-Robin Brainstormingapproachbetter thanstudents who receivedconventional teaching.
\end{abstract}

Keywords: Round-Robin Brainstorming, mathematics communication 


\section{PENDAHULUAN}

Pendidikan matematika adalah bagian dari pendidikan nasional yang diwajibkan bagi semua siswa yang menempuh pendidikan mulai dari tingkat sekolah dasar sampai tingkat sarjana.Salah satu kemampuan yang harus dikuasai siswa dalam pembelajaran matematika berdasarkan KTSP dan NCTM adalah komunikasi matematis.

Kemampuan komunikasi harus dimiliki agar siswa dapat memahami permasalahan matematika yang diberikan dan mengutarakan ide-ide penyelesaian dari permasalahan tersebut, serta memberikan argumen atas idea yang diutarakannya. Materi matematika disampaikan melalui suatu bahasa yang universal. "Salah satu ciri utama matematika adalah penggunaan simbol-simbol untuk menyatakan sesuatu, misalnya menyatakan suatu fakta, konsep operasi ataupun prinsip/aturan." (Soedjadi, 2000:199). Kusumah (Hutapea, 2013) menyatakan bahwa melalui komunikasi, memungkinkan tereksploitasinya ide matematis melalui berbagai perspektif, mempertajam cara berfikir siswa, dapat mengukur perkembangan pemahaman, dapat mengorganisisr pemikiran siswa, dapat mengkonsruksi pengetahuan matematis dan pengembangan masalah siswa, meningkatkan penalaran, dan membentuk komunikasi.

Namun, kemampuan komunikasi siswa di Indonesia masih rendah. Rohaeti dan Purniati (Yuniarti, 2007: 10) menyatakan bahwa rata-rata kemampuan komunikasi matematis siswa masih berada pada kualifikasi sedang, dan pada umumnya respon siswa terhadap soal komunikasi kurang. Begitu pun dalam hasil penelitian Rohaeti dan Wihatma (Hutapea, 2013: 4-5) bahwa rata-rata kemampuan komunikasi matematis siswa berada pada kualifikasi kurang dan dalam mengkomunikasikan ideide matematika termasuk pada kualifikasi kurang sekali.

Banyak faktor yang mempengaruhi keberhasilan siswa dalam belajar matematika. Salah satunya adalah metode pembelajaran yang dilakukan guru di dalam kelas. Suherman, et al (2001) menyatakan bahwa guru seyogyanya memilih dan menggunakan strategi, pendekatan, metode, dan teknik yang dapat secara aktif melibatkan siswa dalam proses pembelajaran. Seperti yang dikemukakan oleh Suherman et al (2001: 60) bahwa "siswa harus dibiasakan untuk diberi kesempatan bertanya dan berpendapat, sehingga diharapkan proses pembelajaran matematika lebih bermakna.

Salah satu pendekatan yang dapat dipakai dalam pembelajaran matematika adalah Brainstorming Round-Robin. Pendekatan Brainstorming Round-Robin adalah Brainstorming (curah pendapat), yang dalam pelaksanaannya setiap siswa diharuskan menyampaikan ide ataupun jawaban dari permasalahan yang diberikan. Tahapan-tahapan pada pendekatan Brainstorming Round-Robin memberikan siswa kesempatan untuk dapat mengasah kemampuan komunikasi. Seperti yang 
dikemukakan Baroody (Martinho dan Ponte, 2008) bahwa pertanyaan yang diberikan oleh guru melatih kemampuan komunikasi siswa.

Berdasarkan pemaparan di atas, rumusan masalah dalam penelitian ini adalah:Apakah peningkatan kemampuan komunikasi matematis siswa yang pembelajarannya menggunakan Brainstorming Round-Robin lebih baik daripada siswa yang pembelajarannya konvensional?

Adapun tujuan dari penelitian ini adalah untuk menelaah peningkatan kemampuan komunikasi matematis siswa yang pembelajarannya menggunakan Brainstorming Round-Robindibandingkan dengan siswa yang pembelajarannya konvensional.

\section{KAJIAN TEORI}

\section{Komunikasi Matematis}

Baroody (1993) mengemukakan dua alasan mengapa pembelajaran matematika harus berfokus pada komunikasi, yaitu karena matematika adalah bahasa kedua yang sangat penting dan matematika sebenarnya adalah suatu kegiatan sosial.Penggunaan komunikasi berupa ucapan dan tulisan oleh guru dan siswa dalam pembelajaran matematika, sangat penting untuk membangun konsep matematika siswa yang kemudian membangun mathematical thinking (Huang dan Normandia, 2009).

Kemampuan komunikasi matematis, menurut Herdian (2010) adalah suatu kemampuan siswa dalam menyampaikan sesuatu yang diketahuinya melalui peristiwa dialog atau saling hubungan yang terjadi di lingkungan kelas, dimana terjadi pengalihan pesan. Lebih lanjut, Sulivan dan Mousley (Wulanratmini, 2011: 40) mengemukakan bahwa "komunikasi matematis tidak hanya sekedar menyatakan ide melalui tulisan tetapi lebih luas lagi yaitu kemampuan siswa dalam hal menyatakan, menjelaskan, menggambarkan, mendengar, menanyakan dan bekerjasama."

\section{Braistorming Round Robin}

Brainstorming Round-Robin merupakan salah satu pembelajaran kooperatif. pertama kali dicetuskan oleh Dr. Spencer Kagan dan rekannya pada Kagan Publishing and Professional Development.Penggunaan Brainstorming Round-Robinbertujuan untuk memberi kesempatan kepada siswa untuk mengungkapkan ide/gagasandengan cara yang efektif dan cepat (Alberta Education, 2008).Round-Robinsendiri adalah brainstormingyang di dalam pelaksanaannya siswa hanya dibenarkan untuk mengajukan gagasan saja tanpa menjelaskan, mengevalusi ataupun mempertanyakan gagasan yang diajukan siswa lain (Barkley, Cross dan Major, 2005). 
Tahapan Brainstorming Round-Robin menurut Kagan (Ledlow,1995): (1) mendengarkan pertanyaan; (2) berfikir tentang semua jawaban yang mungkin cocok; (3) menyumbangkan satu jawaban dengan suara keras; (4) mendengarkan satu jawaban yang akan diberikan oleh teman satu tim; (5) menyumbangkan jawaban tambahan yang belum disebutkan orang lain ketika mendapat bagian lagi; (6) mendengarkan jawaban tambahan dari teman sekelompok; (7) terus menyumbangkan jawaban, satu dalam setiap waktu, sampai waktunya habis.Setiap siswa dalam kelompok dapat melewatkan gilirannya untuk menjawab, dan dapat menjawab lagi ketika mempunyai gagasan atau jawaban lain (Heartland Area Education Agency 11, 2006).

\section{METODE PENELITIAN}

Penelitian merupakan penelitian kuasi eksperimendengan desain non equivalent pretest and post-test control group design (Ruseffendi, 2010) sebagai berikut:

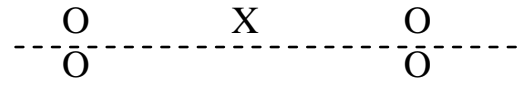

Keterangan:

X : Perlakuan menggunakan Pendekatan Brainstorming Round-Robin

$\mathrm{O} \quad$ : Pretes atau Postes kemampuan komunikasimatematis

Populasi dalam penelitian ini adalah seluruh siswa kelas VII di salah satu SMP negeri di Kabupaten Bandung Barat dengan sampel dua kelas, kelas VII-H sebagai kelas eksperimen dan kelas VII-I sebagai kelas kontrol. Adapun instrumen yang digunakan adalah seperangkat soal tes kemampuan komunikasi matematis.

\section{HASIL DAN PEMBAHASAN}

Tabel 1

Rekapitulasi Hasil Pretes, Postes dan Gain Kemampuan Komunikasi Matematis

\begin{tabular}{|c|c|c|c|c|c|c|c|}
\hline \multirow{2}{*}{ Pembelajaran } & \multirow{2}{*}{$\mathrm{n}$} & \multicolumn{2}{|c|}{ Pretes } & \multicolumn{2}{|c|}{ Postes } & \multicolumn{2}{|c|}{ N-Gain } \\
\hline & & $\bar{x}$ & $s$ & $\bar{x}$ & $S$ & $\bar{x}$ & $s$ \\
\hline $\begin{array}{l}\text { Brainstorming } \\
\text { Round-Robin }\end{array}$ & 39 & 0,82 & 1,47 & 5,15 & 2,70 & 0,39 & 0,21 \\
\hline Konvensional & 35 & 1,26 & 0,88 & 3,83 & 1,74 & 0,23 & 0,17 \\
\hline
\end{tabular}

Keterangan : Skor Ideal Tes Kemampuan Komunikasi Matematik = 12

Berdasarkan Tabel 1, dari hasil pretes diketahui bahwa kemampuan komunikasi matematisawal kelas Brainstorming Round-Robin dan kelas konvensional tidak jauh 
berbeda. Selanjutnya rerata skor postes kemampuan komunikasi matematis yang didapat kelas Brainstorming Round-Robinlebih baik daripadaskor postes yang diperoleh kelas konvensional. Begitupun dengan rerata gain pada kelas Brainstorming Round-Robinlebih baik daripada rerata gain pada kelas konvensional.

Hasil perolehan di atas selanjutnya diuji dengan menggunakan uji perbedaan rerata untuk mendukung dekripsi peningkatan kemampuan komunikasi matematis.

\section{Uji Normalitas Rerata $\mathbf{N}$-gain}

Hasil perhitungan uji normalitas dengan menggunakan SPSS 21 terhadap rerata data $\mathrm{N}$-gain, dengan taraf kepercayaan 95\% disajikan dalam Tabel 2.

Tabel 2

Data Hasil Uji Normalitas Rerata N-gain Kemampuan Komunikasi Matematis

\begin{tabular}{ccccc}
\hline \multirow{2}{*}{ Pembelajaran } & \multicolumn{2}{c}{ Saphiro-Wilk } & \multirow{2}{*}{ Kesimpulan } \\
& $\mathrm{N}$ & Sig. & \\
Gain & $\begin{array}{c}\text { Brainstorming } \\
\text { Round-Robin } \\
\text { Konvensional }\end{array}$ & 39 & 0,172 & Normal \\
& Kon & 0,000 & Tidak Normal \\
\hline
\end{tabular}

Tabel 2 menunjukkan kedua data tidak berdistribusi normal. Oleh karena itu pengujian perbedaan dua rerata dilakukan dengan menggunakan uji Mann-Whitney.

\section{Uji Perbedaan Rerata N-gain}

$H_{o}: \mu_{1}=\mu_{2}$

$H_{a}: \mu_{1}>\mu_{2}$

Kriteria pengujian : jika sig.> 0,05 maka $H_{0}$ diterima

Adapun hasil perhitungan disajikan dalam Tabel 3 di bawah ini:

Tabel 3

Data Hasil Uji Perbedaan Rerata N-gain Kemampuan Komunikasi Matematis

\begin{tabular}{|c|c|c|c|c|c|}
\hline \multicolumn{2}{|c|}{ Pembelajaran } & $\begin{array}{c}\text { Sig. } \\
\text { Mann-Whitney } \\
\text { (2-pihak) }\end{array}$ & $\begin{array}{c}\text { Sig. } \\
\text { Mann-Whitney } \\
\text { (1-pihak) }\end{array}$ & Ket. & Kesimpulan \\
\hline $\mathrm{N}$-gain & $\begin{array}{l}\text { Brainstorming } \\
\text { Round-Robin } \\
\text { Konvensional }\end{array}$ & 0,006 & 0,003 & $\mathrm{H}_{\mathrm{o}}$ Ditolak & $\mathrm{H}_{a}$ Diterima \\
\hline
\end{tabular}

Hasil perhitungan uji perbedaan rerata pada Tabel 3 menunjukkan signifikansi (2pihak) hasil perhitungan uji Mann-Whitney dari data N-gain adalah 0,006. Sehingga 
dapat dihitung sig. (1-pihak) $=\frac{1}{2} \times 0,006=0,003$. Nilai signifikansi ini lebih kecil dari 0,05 , maka $\mathrm{H}_{\mathrm{o}}$ ditolak. Artinya, peningkatan kemampuan komunikasi matematis siswa yang memperoleh pembelajaran menggunakan pendekatan BrainstormingRound-Robin secara signifikan lebih baik daripada siswa yang memperoleh pembelajaran konvensional.

\section{KESIMPULAN}

Berdasarkan hasil analisis data dan pembahasan sebelumnya, diperoleh kesimpulanPeningkatan kemampuan komunikasi matematis siswa yang pembelajarannya menggunakan pendekatan Brainstorming teknik Round-Robin lebih baik daripada siswa yang pembelajarannya konvensional. Peningkatan pada kelas Brainstorming teknik Round-Robin termasuk kategori sedang, sedangkan peningkatan pada kelas kontrol termasuk kategori rendah.

\section{DAFTAR PUSTAKA}

Alberta Education (2008). French as a Second Language Guide for Implementatition-Grade 10 to Grade 12 (Three-Year). [online]. Tersedia: http://education.alberta.ca/media/904583/app15.pdf . [02 Februari 2013].

Barkley, E.E., Cross, K.P., and Major, C.H. (2005). Collaborative Learning Techniques. New York: Jossey-Bass.

Baroody, A, J. (1993). Problem Solving, Reasoning, and Communicating, (K-8): Helping Children Think Mathematically. New York: Merrill as imprint of Macmillan Publishing Company.

Heartland Area Education Agency 11. (2006). Strategi and Tools for Group Processing. [online].

Tersedia: http://learningteams.pbworks.com/f/Facilitation+Tools+\%26+Strategies.pdf.

Herdian. (2010). Kemampuan Komunikasi Matematika. [online]. Tersedia: http://herdy07.wordpress.com/2010/05/27/kemampuan-komunikasimatematis/\#more-1027.

Huang J dan Normandia B. (2009). "Students' Perceptions on Communicating Mathematically: A Case Study of a Secondary Mathematics Classroom". The International Journal of Learning. 16, (5).

Hutapea, N.M. (2013). Peningkatan Kemampuan Penalaran, Komunikasi Matematis dan Kemandirian Belajar Siswa SMA melalui Pembelajaran Generatif. Disertasi pada SPS UPI Bandung: Tidak Diterbitkan.

Ledlow, S (1995). Instructions for Roundrobin Brainstorming. Arizona State University. [online].

Tersedia: http://www.hydroville.org/system/files/team_roundrobin.pdf. $\quad[22$ januari 2013]. 
Matrinho, M. H dan Ponte, J.P. (2008). A Collaborative Project as a Learning Opportunity for Mathematics Teachers. The International Congress on Mathematical Education. eds 11. Monterrey.

Ruseffendi, E. T. (2010). Dasar-Dasar Penelitian Pendidikan dan Bidang NonEksakta Lainnya. Edisi Cetak Pertama. Bandung.: Tarsito.

Soedjadi, R (2000). Kiat Pendidikan Matematika di Indonesia. Jakarta: Direktorat Jenderal Pendidikan Tinggi Departemen Pendidikan Nasional.

Suherman, et al. (2001). Strategi Pembelajaran Matematika Kontemporer. Bandung: JICA-UPI.

Wulanratmini, D. (2011). Peningkatan Kemampuan Penalaran dan Komunikasi Matematis dengan Pendekatan Creative Problem Solving melalui Media Geogebra di Kota Bandung Propinsi Jawa Barat. Tesis pada SPs UPI Bandung: Tidak Diterbitkan.

Yuniarti, Y. (2007). Meningkatkan Kemampuan Penalaran dan Komunikasi Matematis Siswa SMP melalui Pembelajaran dengan Pendekatan Inkuiri. Tesis pada PPs UPI: Tidak Diterbitkan. 